\title{
Evaluation of Lactose-Based Direct Tableting Agents' Compressibility Behavior Using a Compaction Simulator
}

\author{
Sıkıştırma Simülatörü Kullanarak Laktoz Bazlı Doğrudan Tabletleme \\ Ajanlarının Sıkıştırabilme Davranışlarının Değerlendirilmesi
}

\author{
(D) Yıldız ÖZALP*, (D) Motunrayo M. ONAYO, (D) Nailla JIWA \\ Near East University Faculty of Pharmacy, Department of Pharmaceutical Technology, Nicosia, Cyprus
}

\begin{abstract}
Objectives: A compaction simulator (CS) is a single-punch instrument that records data during the powder compaction process. The aim of the study was to determine the behavior of lactose-based direct tableting agents (DTAs) by CS. The data recorded were used to evaluate the flowability and compressibility of powders. The focus of the study was on comparing the compressibility of StarLac ${ }^{\circledR}$ [alpha lactose monohydrate (85\%) and white maize starch (15\%)] and FlowLac ${ }^{\circledR 100}$ (spray-dried alpha lactose monohydrate) in order to make tablets containing poorly flowable paracetamol.

Materials and Methods: Two lactose-based DTAs were used. Physical characterization of these powders was done by measuring bulk, tapped, and true densities alongside scanning electron microscopy analysis. Flow properties were then calculated by the angle of repose, Hausner ratio, and Carr's compressibility index. Force, in-die thickness, and punch displacement data produced by the CS were captured during in-die compression. Compressibility was calculated using the Heckel equation.

Results: The physical characterization test results showed no significant difference between the two DTAs. Hardness results revealed that tablet formulations containing FlowLac ${ }^{\circledR}$ had higher sensitivity to an increase in compression force in comparison with StarLac ${ }^{\circledR}$. From the Heckel plots generated by the CS during the compression cycle, yield pressure $\left(P_{y}\right)$ values were calculated for FlowLac ${ }^{\circledR} 100$ and StarLac ${ }^{\circledR}$. The Heckel parameter $\left(P_{y}\right)$ for FlowLac ${ }^{\oplus 100}$ and StarLac ${ }^{\circledR}$ was calculated as $87.5 \mathrm{MPa}$ and $85.2 \mathrm{MPa}$, respectively, during the compaction cycle at $5 \mathrm{kN}$. These data indicated that both powders are compressible and have brittle behavior.

Conclusion: StarLac ${ }^{\circledR}$ is less brittle, which was shown by its lower sensitivity to compression force. $P_{y}$ values obtained from the Heckel equation described the plasticity of particles, which gives distinct information on the compressibility of both DTAs in real time during the compaction cycle. Key words: Compaction simulator, compressibility, tablet, FlowLac ${ }^{\oplus 100}$, StarLac $^{\circledR}$
\end{abstract}

öz

Amaç: Sıkıştırma simülatorü (CS) toz sıkıştırma prosesi sırasında veri kaydı yapan tek zımbalı bir cihazdır. Bu çalıșmanın amacı laktoz bazlı doğrudan tabletleme ajanlarının (DTA) davranıșlarını CS kullanarak belirlemektir. Kaydedilen veriler tozların basılabilme ve akıș özelliklerini değerlendirmede kullanılmıştır. Çalışmanın odağı zayıf akış özelliğine sahip parasetamol içeren tabletler yapmak için StarLac ${ }^{\circledR}$ [alfa laktoz monohidrat (\%85) ve mısır nişastası \%15)] ve FlowLac ${ }^{\circledR} 100$ (püskürterek kurutulmuș alfa laktoz monohidrat) basılabilirliğini karşılaştırmaktır.

Gereç ve Yöntemler: İki laktoz bazlı DTA kullanılmışıı. Bu tozların bulk, sıkıştırılmış ve gerçek yoğunlukları yansıra fiziksel özellikleri taramalı elektron mikroskobu analiziyle birlikte görüntülenmiştir. Daha sonra akış özellikleri yığın açısı, Hausner oranı ve Carr basılabilirlik indeksleri hesaplanmıştır. CS tarafından üretilen kuvvet, sıkışmış tozun zımba içindeki kalınlığı ve zımba deplasmanı verileri iç kompresyon esnasında elde edilmiştir. Basılabilirlik Heckel eşitliği kullanılarak hesaplanmıştır.

Bulgular: Fiziksel karakterizasyon test sonuçları iki DTA arasında anlamlı bir fark göstermemiştir. Sertlik sonuçları FlowLac ${ }^{\circledR}$ içeren tablet formülasyonların StarLac ${ }^{\circledR}$ içeren formülasyonlara göre baskı gücünün artışına karşı daha yüksek hassasiyet gösterdiklerini açığa çıkarmıştır. Baskı döngüsü esnasında, CS tarafından oluşturulan Heckel plotlarından FlowLac ${ }^{\circledR 100}$ and StarLac ${ }^{\circledR}$ için verim basıncı $\left(P_{y}\right)$ hesaplanmıştır. kM'de sıkıştırma döngüsü esnasında FlowLac ${ }^{\circledR 100}$ and StarLac ${ }^{\circledR}$ için Heckel parametreleri $\left(P_{y}\right)$ sırasıyla 87,5 MPa ve 85,2 MPa olarak hesaplanmıştır. Bu veriler iki tozun da sıkıștırılabilir olduğunu ve kırılgan davranış gösterdiğine işaret etmiştir.

*Correspondence: E-mail: yildiz.ozalp@neu.edu.tr, Phone: +90 5324630008 ORCID-ID: orcid.org/0000-0001-7928-1666

Received: 12.04.2019, Accepted: 16.04.2019

Turk J Pharm Sci, Published by Galenos Publishing House. 
Sonuç: StarLac ${ }^{\circledast \prime} ı n$ daha az kırılgan olduğu baskı kuvveti uygulamasına karşı daha az duyarlı olduğu ile gösterilmiştir. Heckel eșitliğinden elde edilen partiküllerin plastisitesini tarif etmektedir ve bu da sıkıștırma döngüsü esnasında her iki DTA'nın da sıkıștırabilirlikleri hakkında belirgin bilgi vermektedir.

Anahtar kelimeler: Sıkıștırma simülatorü, sıkıștırabilirlik, tablet, FlowLac ${ }^{\circledR 100}$, StarLac ${ }^{\circledR}$

\section{INTRODUCTION}

A compaction simulator (CS) works by mimicking the exact cycle of any tabletting process in real time and records all important parameters during a single compression cycle. It has a wide range of advantages in industrial production and pharmaceutical research, having the ability to perform scale-up, understand compaction behavior, and characterize powders. Data obtained from measurements of forces and displacement of upper and lower punches as well as plastic and elastic energies are used to evaluate the deformation characteristics of pharmaceutical powders.

Direct tableting agents (DTAs) are incorporated into formulations to improve the flow and compressibility of poorly flowable paracetamol. The primary function of DTAs in a tablet is to act as a carrier for the active pharmaceutical ingredient (API). ${ }^{2}$ The focus of the present study was on lactose-based powders, which are generally used to enhance the bulk of a tablet, flow, and tableting properties. The two DTAs evaluated in our study were FlowLac ${ }^{\circledR} 100$ (spray-dried alpha lactose monohydrate) and StarLac ${ }^{\circledR}$ (co-processed maize starch and lactose). Lactose is a commonly used agent in tablet formulations. Lactose exhibits poor binding properties as a result of particle fragmentation, which is considered the main consolidation mechanism of lactose. ${ }^{3}$

Characterization of powders can be achieved using various compression equations that have been derived by many researchers. 4-10 $^{-10}$ Heckel equation, proposed by Heckel in 1961, which characterizes materials according to plastic and brittle properties, has been widely used in compaction studies.11 The yield pressure, which is calculated from the Heckel equation, follows first-order kinetics. Yield pressure $\left(P_{y}\right)$ is the stress at which a material begins to plastically deform. A low $P_{y}$ value indicates that a material will deform plastically and higher $P_{y}$ values indicate brittle deformation. ${ }^{12}$ Attempts have been made by mechanical descriptors to set limits on these values, allowing materials to be categorized. ${ }^{13}$ Although these limits are present, it has been reported that there may be factors that affect the yield pressure, which may give rise to variations in the $P_{y}$ values for the same material. ${ }^{14-17}$

The target of the present study was to see how both DTAs improve the compactibility characteristics of the model API with the aid of data produced by a compaction simulator.

\section{MATERIALS AND METHODS}

Paracetamol USP grade (Kimetsan) was used with the DTA StarLac ${ }^{\circledR}$ (Meggle AG). StarLac ${ }^{\circledR}$ is co-processed by the spray-drying of $\alpha$-lactose monohydrate and corn starch. For comparison, FlowLac ${ }^{\circledR} 100$ (spray-dried alpha lactose monohydrate, Meggle AG) was used. Stearic acid (Kimetsan) was added to all formulations as lubricant.

\section{Material characterization}

The bulk and tapped densities of the dry sieved raw materials were determined. Bulk and tapped densities were measured using an ERWEKA ${ }^{\circledR}$ tapped volumeter (type: SMV 101/SMV 102, Germany). First the powder was transferred to a $50 \mathrm{~mL}$ graduated glass cylinder with the aid of a funnel. After that the sample was weighed on an analytical balance. The glass cylinder was placed on the tapped volumeter and tapped up to 100 times. The volume of the substance was visually detected and the tapped and bulk densities were calculated. The true densities of substances were determined using a helium pycnometer.

\section{Microscopy}

Particle morphology of the powders used was assessed by scanning electron microscopy (SEM).

\section{Formulation design}

The tablet formulations in this study are shown in Table 1. Formulations were made to compare the compressibility of StarLac ${ }^{\circledR}$ [alpha lactose monohydrate (85\%) and white maize starch (15\%)] and FlowLac ${ }^{\circledR} 100$ (spray-dried alpha lactose monohydrate) in order to make tablets containing poorly flowable paracetamol.

\section{Preparation of powder blends and granulation}

The process of dry granulation was employed in the present study to ensure a uniform granulated powder ready for tableting. Slugging was performed in place of roller compaction. The API was fed into a large capacity tablet press (Korsch XP 1) and was compacted by means of flat punches $18 \mathrm{~mm}$ in diameter. The slugs were then milled and screened through a $0.63-\mathrm{mm}$ mesh sieve. Four formulations were prepared, and a fixed amount of FlowLac ${ }^{\circledR} 100$ or StarLac ${ }^{\circledR}$ was weighed and mixed with $300 \mathrm{mg}$ of $\mathrm{API}$ granules and $10 \mathrm{mg}$ of lubricant in a cubic mixer (ERWEKA ${ }^{\circledR}$ Heusenstamm Germany, type KB 15, serial no. 73876. 1070) for $5 \mathrm{~min}$ at a mixing speed of $50 \mathrm{rpm}$.

\section{Compression procedures}

The tablets were compressed on a Stylcam 200R Compaction Simulator (Medepharm, France). Flat-faced punches $11.28 \mathrm{~mm}$ in diameter were used. The tablets were compressed using 15

Table 1. Formulation composition

Formulations for tabletting (mg)

\begin{tabular}{lllll}
\hline Formulation & Paracetamol & FlowLac $^{\circledR} 100$ & StarLac $^{\circledR}$ & Stearic acid \\
\hline F01 & - & 500 & - & 10 \\
\hline F02 & - & - & 500 & 10 \\
\hline F03 & 300 & 200 & - & 10 \\
\hline F04 & 300 & - & 200 & 10 \\
\hline
\end{tabular}


$\mathrm{kN}$ and $30 \mathrm{kN}$ force to determine the compressibility of the API. The CS recorded upper and lower punch displacement data, which were analyzed using the software ANALIS.

\section{Determining tablet properties}

Ten tablets were made for each formulation at $5,10,15$, and $20 \mathrm{kN}$. Physical tests were carried out on an average of three of them. The crushing strength for each formulation was measured with an ERWEKA ${ }^{\circledR}$ tablet hardness tester $(\mathrm{TBH} 225$ series). Thickness and diameter were also measured.

\section{Heckel analysis}

The Heckel equation is an experimental equation that interprets the relationship between the densification of a powder bed and applied stress.

$\ln \left(\frac{1}{1-D}\right)=K P+$ Intercept

$D$ is the relative density of the powder, $P$ is pressure, and $K$ is a constant and the slope of the linear portion of the graph. The Heckel parameter, denoted by $1 / K$ (inverse of the slope), is thought to be related to the $P_{y}$ of the powder and has the unit of pressure. The arch at low pressure often seen before the linear region on a Heckel plot is due to rearrangement or fracture..$^{4,11,18}$

\section{Statistical analysis}

The study data were analyzed using One-Way ANOVA. The software package IBM SPSS statistics v26 was used. The level of significance was $\mathrm{p}<0.05$.

\section{RESULTS}

The powder flowability was determined by measuring and calculating the angle of repose, the Hausner ratio, and Carr's index. As expected, the results in Table 2 show that the flow properties of paracetamol granules were poor. FlowLac ${ }^{\circledR 100}$ and StarLac ${ }^{\circledR}$ showed excellent flow properties as indicated by the Hausner ratio (1.14 and 1.17, respectively).

In Figures 1a and 1b the SEM images show the similarity in particle structure between FlowLac ${ }^{\circledR} 100$ and StarLac ${ }^{\circledR}$. Both the fillers appeared to have spherical particles with rough surfaces and their particle sizes are within close range (Meggle).

Figures $2 \mathrm{a}$ and $2 \mathrm{~b}$ illustrate the in-die Heckel plots, which were obtained for F01 and F02. In (1/1-D) was calculated for the formulations within a range of compaction forces and these were plotted against each other to determine $P_{y}$.

The variations observed in $\mathrm{P}_{y}$ for both materials can be attributed to the effect of compaction pressure as shown in Tables 3a and $3 b$. Yield stress $\left(P_{y}\right)$ showed a progressive increase with
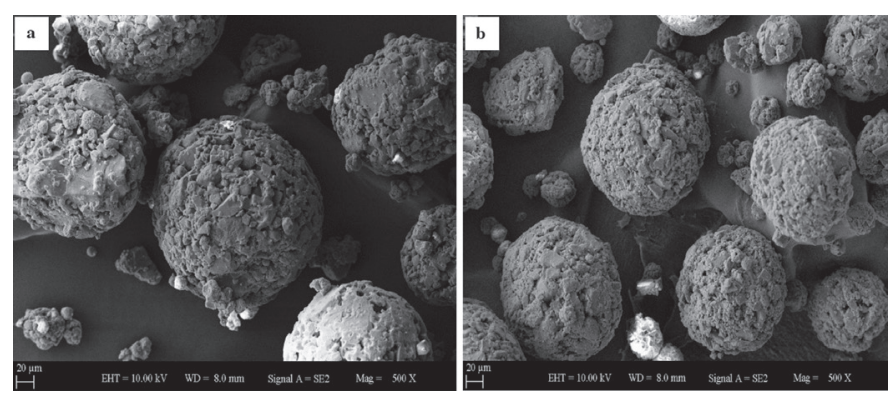

Figure 1a, 1b. Scanning electron microscopy images of the DTAs used in this study (500x):

a) StarLac ${ }^{\circledR}$ b) FlowLac ${ }^{\circledR 100}$

DTAs: Direct tableting agents

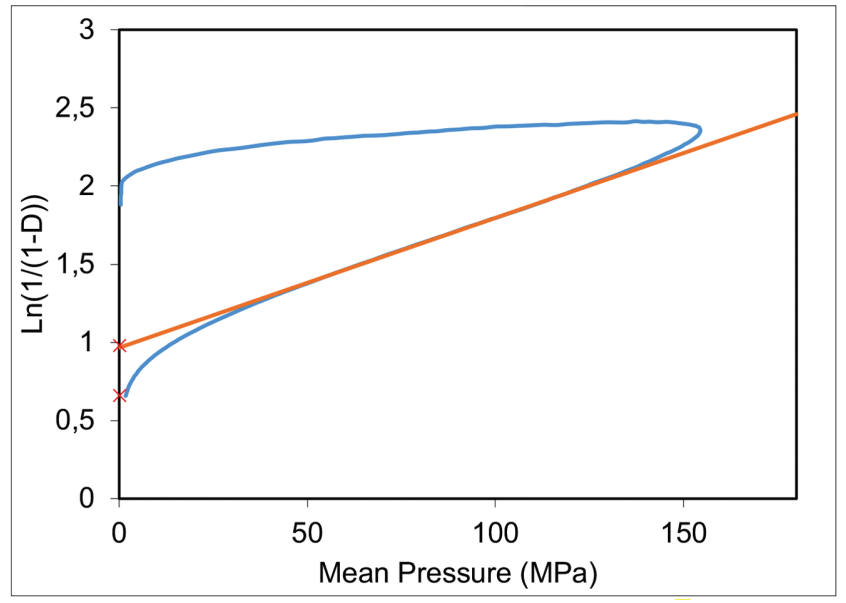

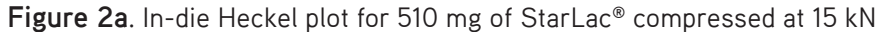

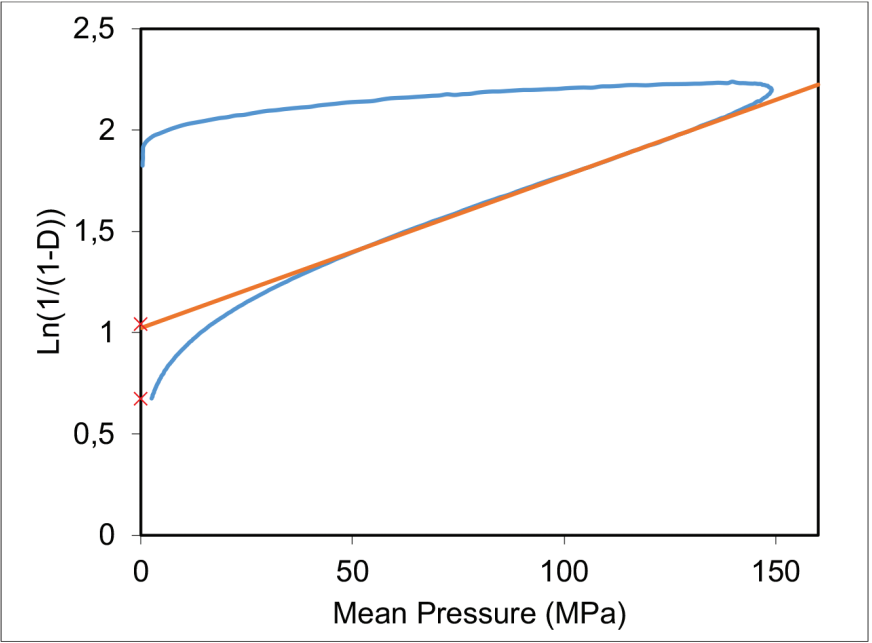

Figure 2b. In-die Heckel plot for 510 mg of FlowLac ${ }^{\circledR} 100$ compressed at $15 \mathrm{kN}$

Table 2. Powder physical properties

\begin{tabular}{|c|c|c|c|c|c|c|c|}
\hline Powders & $\begin{array}{l}\text { Bulk density } \\
(\mathrm{g} / \mathrm{L})\end{array}$ & $\begin{array}{l}\text { Tapped density } \\
\text { (g/L) }\end{array}$ & Hausner ratio & Flow character & $\begin{array}{l}\text { Carr's index } \\
\text { (\%) }\end{array}$ & $\begin{array}{l}\text { Angle of repose } \\
\left({ }^{\circ}\right)\end{array}$ & Flow properties \\
\hline Granulated paracetamol & 44 & 80 & 1.8 & Very, very poor & 44 & 50 & Poor \\
\hline StarLac ${ }^{\circledR}$ & 609 & 714 & 1.17 & Good & 14.6 & 19.79 & Excellent \\
\hline
\end{tabular}


increase in compression force. This indicated that yield stress is pressure dependent.

The Heckel analysis showed that for both formulations, F01 and $\mathrm{FO2}$, an increase in compaction pressure resulted in an increase in relative densities, thus signifying that a higher degree of densification occurred at higher pressures.

Figure 3 shows the hardness profiles for the formulations made. There was a greater decrease in crushing strength for FlowLac ${ }^{\circledR 100}$ containing formulations as the compression force increased. However, the sensitivity of StarLac ${ }^{\circledR}$ to change in compression force was less.

\section{DISCUSSION}

The calculated yield pressures for both formulations from Figures $2 \mathrm{a}$ and $2 \mathrm{~b}$ were greater than $80 \mathrm{MPa}$. In accordance with the limits set by Roberts and Rowe ${ }^{14}$ both powders would be considered brittle materials. Generally, a lower $P_{y}$ value (higher slope) reflects lower resistance to pressure, better densification, higher plastic deformation ability, and improved compressibility. ${ }^{19}$

Duberg and Nyström ${ }^{20}$ divided the Heckel plot into two phases: compression and decompression. For an elastic material the curve shows a noticeable deviation from the horizontal in the decompression phase, which then leads to a low $P_{y}$ value. As expected, the lactose-based excipients showed no deviation from the horizontal.

The Heckel analysis showed that for both formulations, F01 and F02, as the compaction pressure increased, values of relative density increased. Hence, a higher degree of densification occurred at higher pressures. In concurrence with previous studies, $18,21 \quad$ StarLac ${ }^{\circledR}$ had lower $P_{y}$ when compared to FlowLac ${ }^{\circledR 100}$; therefore, the values of $P_{y}$ were higher for F01 at all compaction pressures compared to F02. These findings also indicate that more densification was exhibited by $\mathrm{FO} 2$ and this could be attributed to the low resistance to force as seen in Figure 3. This may also be attributed to the different physical properties of the DTAs.

The confidence level of $95 \%$ gives a clear indication of variation between $\mathrm{P}_{\mathrm{y}}$ of both DTAs, with a significant difference value ( $p<0.05)$.

The reduced densification of F01 (FlowLac ${ }^{\circledR 100)}$ ) can be associated with increased frictional and cohesive forces, which tend to restrain particle sliding. This leads to a relatively small amount of fragmentation and thus formation of less dense compacts. ${ }^{14}$

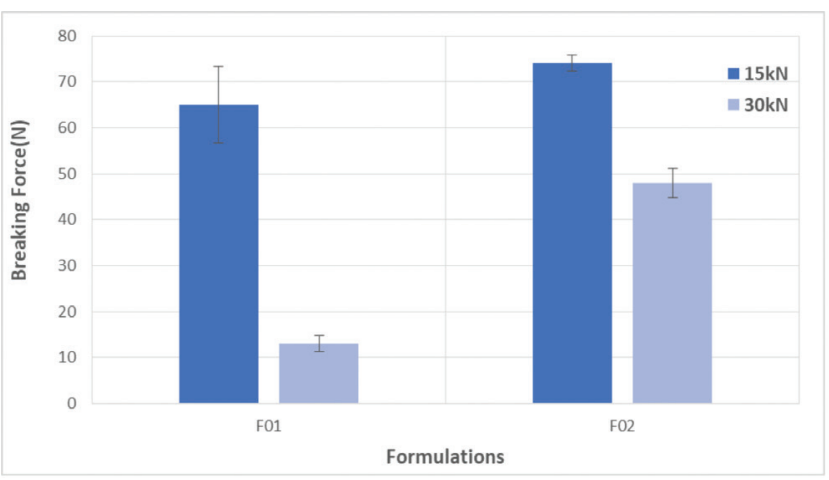

Figure 3. Hardness profiles of formulations at different compaction forces

Table 3a. Mean yield pressure, densification due to initial die filling, elastic energy, plastic energy, and $\mathrm{R}^{2}$ values obtained from in-die Heckel analysis for FlowLac ${ }^{\circledR 100}$

\begin{tabular}{lllllll}
$\begin{array}{l}\text { Compression } \\
\text { force }(\mathrm{kN})\end{array}$ & $\mathrm{P}_{\mathrm{y}}(\mathrm{MPa})$ & $\mathrm{R}^{2}$ & $\mathrm{D}_{0^{*}}$ & $\mathrm{EE}$ & $\mathrm{PE}$ & $\mathrm{EE} / \mathrm{PE}$ ratio \\
\hline $5(0.2)$ & $87.5(0.95)$ & $0.995(0.001)$ & $0.300(0.066)$ & $0.083(0.009)$ & $3.662(0.064)$ & $0.023(0.002)$ \\
\hline $10(1.8)$ & $119.5(9.25)$ & $0.997(0.002)$ & $0.363(0.066)$ & $0.202(0.020)$ & $6.828(0.053)$ & $0.030(0.002)$ \\
\hline $15(0.3)$ & $138.0(2.57)$ & $0.996(0.002)$ & $0.383(0.046)$ & $0.385(0.017)$ & $9.736(0.171)$ & $0.041(0.001)$ \\
\hline $20(0.4)$ & $145.5(1.78)$ & $0.996(0.000)$ & $0.408(0.013)$ & $0.617(0.100)$ & $12.249(0.10)$ & $0.050(0.001)$ \\
\hline
\end{tabular}

$n=3$ with standard deviations in parentheses, *values of $D_{0}$ are derived from the subtraction of densification due to slippage and rearrangement of primary particles $\left(D_{b}\right)$ from densification due to initial particle rearrangement $\left(D_{a}\right)$

$P_{y}$ : Yield pressure, EE: Elastic energy, PE: Plastic energy

Table 3b. Mean yield pressure, densification due to initial die filling, elastic energy, plastic energy, and $\mathrm{R}^{2}$ values obtained from in-die Heckel analysis for StarLac ${ }^{\circledR}$

\begin{tabular}{lllllll}
$\begin{array}{l}\text { Compression } \\
\text { force }(\mathrm{kN})\end{array}$ & $\mathrm{P}_{\mathrm{y}}(\mathrm{MPa})$ & $\mathrm{R}^{2}$ & $\mathrm{D}_{0^{*}}$ & $\mathrm{EE}$ & $\mathrm{PE}$ & $\mathrm{EE} / \mathrm{PE}$ ratio \\
\hline $5(0.2)$ & $85.2(1.115)$ & $0.998(0.001)$ & $0.223(0.006)$ & $0.078(0.004)$ & $3.529(0.091)$ & $0.022(0.001)$ \\
\hline $10(1.8)$ & $112.1(1.553)$ & $0.999(0.000)$ & $0.330(0.000)$ & $0.196(0.012)$ & $6.686(0.119)$ & $0.028(0.001)$ \\
\hline $15(0.3)$ & $121.3(1.595)$ & $0.996(0.001)$ & $0.320(0.030)$ & $0.340(0.026)$ & $9.493(0.215)$ & $0.035(0.002)$ \\
\hline $20(0.4)$ & $118.7(2.476)$ & $0.995(0.000)$ & $0.337(0.031)$ & $0.572(0.067)$ & $12.398(0.01)$ & $0.047(0.005)$ \\
\hline
\end{tabular}

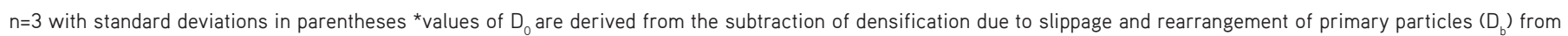
densification due to initial particle rearrangement $\left(D_{a}\right)$

$P_{y}$ : Yield pressure, EE: Elastic energy, PE: Plastic energy 
The data illustrated in Tables 3a and 3b indicated that at different compaction forces the StarLac ${ }^{\circledR}$ tablets exhibited lower elastic energies than FlowLac ${ }^{\circledR 1} 100$ tablets did.

As observed from the hardness profiles of $\mathrm{FO} 3$ and F04, both formulations were compressible and gave suitable crushing strengths at $15 \mathrm{kN}$. Due to the difference in composition of the DTAs, StarLac ${ }^{\circledR}$ gave rise to a combination of deformation mechanisms. This indicates that there was a reduction in the brittle behavior of StarLac ${ }^{\circledR}$.

\section{Study limitation}

A limitation of the study is that slugging may not generate reproducible results and therefore the use of a roller compactor may improve reliability.

To obtain an optimized formulation using the same materials, the study can be expanded by implementing more tablet tests to help design a more robust formulation with the aid of a compaction simulator.

\section{CONCLUSION}

A CS can precisely and efficiently characterize the compressibility of DTAs in a single compression cycle in real time. The low $P_{y}$ of the StarLac ${ }^{\circledR}$ formulation indicated better compressibility in comparison to FlowLac ${ }^{\circledR} 100$. Initial characterization of both DTAs used led to understanding of their deformation behavior from the Heckel parameter $\left(P_{y}\right)$ depicting a brittle nature.

Conflicts of interest: No conflict of interest was declared by the authors. The authors alone are responsible for the content and writing of the paper.

\section{REFERENCES}

1. Çelik M, Marshall K. Use of a Compaction Simulator System in Tabletting Research. Drug Dev Ind Pharm. 1989;15:759-800.

2. Khan K A, Rhodes CT. Effect of Variation in Compaction Force on Properties of Six Direct Compression Tablet Formulation. J Pharm Sci. 1976;65:1835-1837.

3. Bolhuis GK, de Waard H. Compaction properties of directly compressible materials. Pharmaceutical Powder Compaction Technology. CRC Press. 2016;143-204.

4. Klevan I, Nordström J, Bauer-Brandl A, Alderborn G. On the physical interpretation of the initial bending of a Shapiro-Konopicky-Heckel compression profile Eur J Pharm Biopharm. 2009;71:395-401.

5. Adams MJ, McKeown R. Micromechanical analyses of the pressurevolume relationship for powders under confined uniaxial compression. Powder Technology. 1996;88:155-163.
6. Adams MJ, Mullier MA, Seville JPK. Agglomerate strength measurement using a uniaxial confined compression test. Powder Technology. 1994;78:5-13.

7. Denny PJ. Compaction equations: a comparison of the Heckel and Kawakita equations. Powder Technology. 2002;127:162-172.

8. Kawakita K, Lüdde KH. Some considerations on powder compression equations. Powder technology. 1971;4:61-68.

9. Nordström J, Klevan I, Alderborn G. A particle rearrangement index based on the Kawakita powder compression equation. Journal of pharmaceutical sciences. 2009;98:1053-1063.

10. Sonnergaard JM. Investigation of a new mathematical model for compression of pharmaceutical powders. Eur J Pharm Sci. 2001;14:149157.

11. Hooper D, Clarke FC, Mitchell JC, Snowden MJ. A modern approach to the Heckel Equation: The effect of compaction pressure on the yield pressure of ibuprofen and its sodium salt. J Nanomed Nanotechnol. 2016;7:3.

12. Alderborn G. Tablets and compaction Churchill Livingstone. 2007.

13. Rowe RC, Roberts RJ. Mechanical Properties: Pharmaceutical Powder Compaction Technology, Marcel Dekker, Inc;1996.

14. Roberts RJ, Rowe RC. The effect of punch velocity on the compaction of a variety of materials. J Pharm Pharmacol. 1985;37:377-384.

15. Denny PJ. Compaction equations: a comparison of the Heckel and Kawakita equations. Powder Technology. 2002;127:162-172.

16. Fell JT, Newton JM. Effect of particle size and speed of compaction on density changes in tablets of crystalline and spray-dried lactose. J Pharm Sci. 1971;60:1866-1869.

17. Patel S, Kaushal AM, Bansal AK. Effect of particle size and compression force on compaction behavior and derived mathematical parameters of compressibility. Pharm Res. 2007;24:111-124.

18. Mahmoodi F, Klevan I, Nordström J, Alderborn G, Frenning G. A comparison between two powder compaction parameters of plasticity: the effective medium A parameter and the Heckel $1 / \mathrm{K}$ parameter. Int $\mathrm{J}$ Pharm. 2013;453:295-299.

19. Kilicarslan M, Çamca R, Imamoglu S, Antep MN, Ocak B. Yuksel N. Investigation on the flow properties and compresibilities of different direct tableting agents by using pyridoxine hydrochloride as a model drug. J Fac Pharm. 2009;38:331-344.

20. Duberg M, Nyström C. Studies on direct compression of tablets. XVII. Porosity-pressure curves for the characterization of volume reduction mechanisms in powder compression. Powder Technol. 1986;46:67-75.

21. Hauschild K, Picker-Freyer KM. Evaluation of a new co-processed compound based on lactose and maize starch for tablet formulation. AAPS pharmSci. 2004;6:e16. 